\title{
Harsh K. Gupta, Appointed as Member of the National Disaster Management Authority
}

Dr. Harsh K. Gupta, President, Geological Society of India and Panikkar

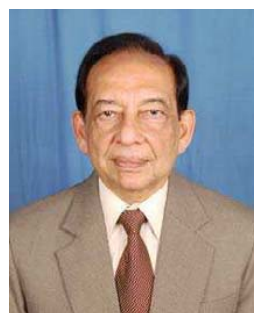

Professor at National

Geophysical Research

Institute (CSIR),

Hyderabad has been

appointed as member

of the National

Disaster Management

Authority (NDMA),
Government of India. The office of Member, NDMA carries the status of Union Minister of State. The NDMA is the Apex Body for Disaster Management in India and constituted with the Prime Minister of India as its Chairman, a Vice Chairman with the status of Cabinet Minister, and seven members with the status of Ministers of State. Each of the members has a well defined functional domain covering various states as also disaster specific areas of focus. NDMA is mandated to lay down the policies, plans and guidelines for Disaster Management to ensure timely and effective response to disasters (http://ndma.gov.in/ ndma/index.html). Appointment as a member, NDMA is a recognition to Dr. Gupta's outstanding scientific contributions in several areas of geosciences. 